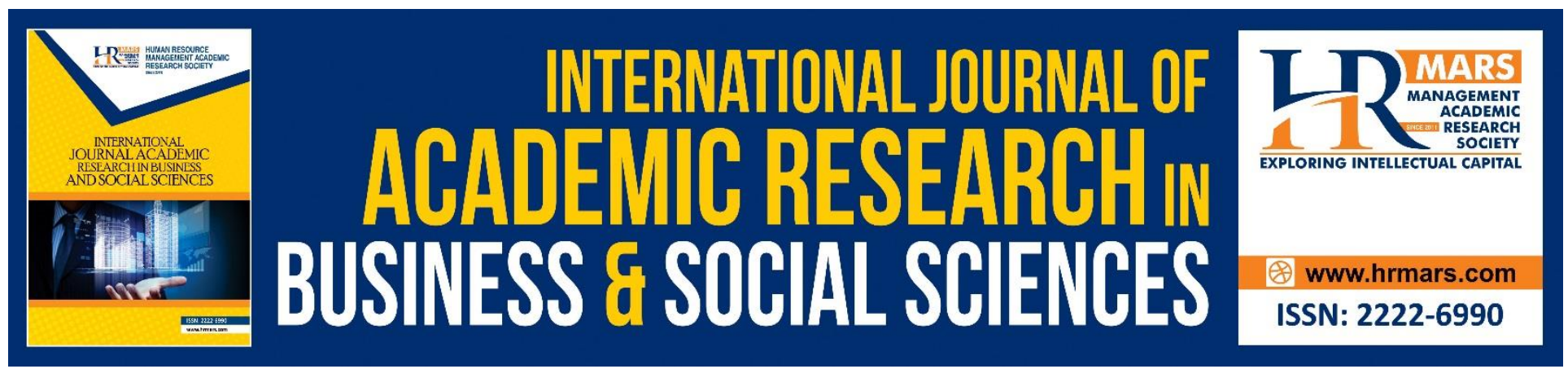

\title{
Analyzing High Interest Rate Spreads in Kenya: Panel Data Approach
}

Stephene Maende, Joseph Mutana, Michael Munga

To Link this Article: http://dx.doi.org/10.6007/IJARBSS/v8-i7/4343

DOI: $\quad 10.6007 /$ IJARBSS/v8-i7/4343

Received: 03 June 2018, Revised: 20 June 2018, Accepted: 29 July 2018

Published Online: 30 July 2018

In-Text Citation: (Maende, Mutana, \& Munga, 2018)

To Cite this Article: Maende, S., Mutana, J., \& Munga, M. (2018). Analyzing High Interest Rate Spreads in Kenya: Panel Data Approach. International Journal of Academic Research in Business and Social Sciences, 8(7), 312327.

Copyright: (C) 2018 The Author(s)

Published by Human Resource Management Academic Research Society (www.hrmars.com)

This article is published under the Creative Commons Attribution (CC BY 4.0) license. Anyone may reproduce, distribute, translate and create derivative works of this article (for both commercial and non-commercial purposes), subject to full attribution to the original publication and authors. The full terms of this license may be seen at: $\underline{\text { http://creativecommons.org/licences/by/4.0/legalcode }}$

\section{Vol. 8, No. 7, July 2018, Pg. 312 - 327}

Full Terms \& Conditions of access and use can be found at http://hrmars.com/index.php/pages/detail/publication-ethics 


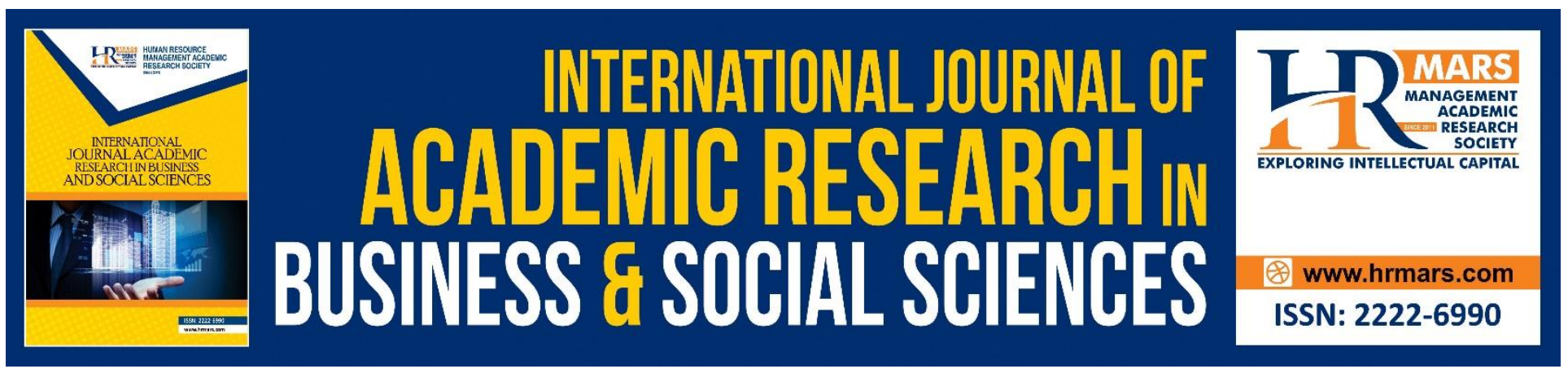

\title{
Analyzing High Interest Rate Spreads in Kenya: Panel Data Approach
}

\author{
Stephene Maende \\ School of Economics, University of Nairobi, Nairobi Kenya \\ Email: maende08@gmail.com \\ Joseph Mutana \\ School of Economics, Moi University, Eldoret Kenya \\ Email: mutanajoseph@gmail.com \\ Michael Munga \\ School of Business, Kenyatta University, Nairobi Kenya \\ Email: michaelmunga30@yahoo.com
}

\begin{abstract}
The study investigated factors behind high interest rate spreads with focus on the Kenyan commercial banks. Ordinary least square model, Fixed and Random effect approaches based on Ho and Saunders (1981) were applied on a panel of 38 commercial banks for the period 2006-2015. The study revealed that bank, industry and macroeconomic factors explain interest rate spreads. However, their impact was weak. We recommend the need to explore both internal and industry-led strategies to reduce the effect of factors associated with the bank.
\end{abstract}

Keywords: Interests, Interest Rate Spreads, Commercial Banks, Ho \& Saunders Model, Panel

\section{Introduction}

\section{Background}

The role of banking industry towards economic growth and development cannot be gainsaid. Banks provides avenues through which resources are mobilized from depositors and then lend to borrowers for either consumption or investment. This therefore means that bank loans contribute to the generation of economic activities which translates to higher national Gross Domestic Product (GDP) (Afzal, 2011). In this case, the efficiency of the financial sector of an economy becomes very important. There are several measures of this efficiency such as the amount of deposits or loans as a ratio to GDP, the number of financial institutions in the economy or interest rate spread/margin (IRS). This paper focused on the later and what determines it. IRS refers to the differences on deposits and lending rates. In Developing countries, such as Kenya, financial sector is characterized with high IRS 
on average than developed countries (Mensah \& Abor, 2012; Kiptui, 2014; Were \& Wambua, 2013). Commercial bank interest rate represents costs incurred by the banks in the intermediation process. This implies that, more welfare benefits can be realized when IRS are low.

We note that higher IRS are an indication of inefficiencies within the financial sector and this has serious consequences on both private and public-sector operations. This is because, investments are often financed by loans and higher interest margins are therefore likely to reduce the levels of investments in the economy. In addition, higher IRS in an economy is likely to discourage financial deepening by keeping away those who would like to save because of low earnings on deposits. This might result into limited ability of the sector to advance loans. Possible business opportunities are therefore reduced and hence the economy's potential growth. Lower interest rate margins on the other hand, encourages financial deepening and more development of financial markets which enhances investment activities and promote economic growth (Dumicic \& Ridzak, 2013).

Studies which examined various factors explaining IRS in both developing and developed economies have classified them into three categories: institutional, market and macroeconomic. For developed countries, Angbazo (1997), Maundos and Guevara (2004) and Gunter et al. (2013) have examined this in USA, European Union and Austria respectively, while in developing countries (particularly the subSaharan region), similar studies were conducted by Ramful (2001), Becky and Hesse (2009), Were and Wambua (2013), Kiptui (2014) among others. Generally, finding from developed countries and those of developing countries differ in terms of bank, industry and macroeconomic specific factors which determine interest rate spread, but shows variations in results because countries differ by their economic, financial and operating environments. For example, Maundos and Solis (2009) found interest variability as a significant factor in determining interest spread in Mexico, which contradicted Afzal (2011) who observed interest rate volatility as insignificant determinant of IRS in Pakistan.

Regionally, Beck and Hesse (2009) noted that both GDP in inflation explained IRS in Uganda. However, these findings were inconsistent with those of Were and Wambua (2013) who found GDP to be insignificant determinant of IRS for the case of Kenya. Furthermore, a recent study in Kenya by Kiptui (2014) found that macroeconomic (GDP, inflation and Exchange rate), bank specific, and industry specific factors are significant determinants of interest spread. These most recent studies in Kenya also differ in terms of the methodology. For example, Were and Wambua used both fixed and random effect regressions while Kiptui on his part employed ordinary least squares approach. Moreover, the results of these studies were found to be outdated because the most recent study (Kiptui, 2014) used data of up to 2011. Arising from these concerns, this study sought to bridge this gap using the most current data (2006-2015). This study contributes to the ever-growing debates on the determinants of IRS in the World, and Kenya in particular. Specifically, we present evidence on the main drivers of IRS in Kenya with an aim of explaining how these are consistent with Ho \& Saunders (1981) theory and empirical findings from previous studies. In addition, deep understanding of factors explaining high IRS in the Kenya's banking sector, help to resolve the debates on the possible causes. Furthermore, findings of the study would enable policy intervention to reduce IRS.

\section{Interest rates in Kenya}

Upon its inception in 1966, Central Bank of Kenya (CBK) pursued policies aimed at keeping interest rates as low as possible to encourage investment (Ngugi, 2001). CBK achieved this objective by 
INTERNATIONAL JOURNAL OF ACADEMIC RESEARCH IN BUSINESS AND SOCIAL SCIENCES Vol. 8, No. 7, July 2018, E-ISSN: 2222-6990 @ 2018 HRMARS

introducing minimum interest rates on lending and savings which were applicable to all financial institutions in the country. Thus, interest rates remained constant because of two reasons. First, there was fear that any changes on the interests could negatively affect investment, and secondly, the country had good economic performance which sustained positive real interest rates. However, CBK became under pressure to adopt a control policy regime following the balance of payment (BOP) crisis of 1971-1972 which had induced negative inflationary pressures leading to negative real saving rate (Were and Wambua, 2013). A cash ratio of $5 \%$ was introduced on commercial banks to reduce these inflationary pressures. The control policy occasioned inefficiencies ${ }^{1}$ in the financial sector where few commercial banks dominated the market and left the stock market almost dormant.

The period between 1974-1979, saw the first review of interest rate under CBK where the maximum lending rate was increased by $1 \%$ (Beck et al.,2010). This reduced the spread by $1 \%$ because the saving rate had gone up by $2 \%$. The coffee boom of 1976/1977 reduced inflation and increased money supply which led to the increase in liquidity ratio in 1978 . This prompted the CBK to reintroduce the cash ratio that was abolished in 1972 following the introduction of liquidity ratio (Ngugi \& Ndungu, 2000). These developments led to a downward shift in inflation which resulted into positive interest rates. This led to some structural changes within the financial sector because the policy encouraged most Kenyans to invest in the sector and Non-Banking Financial Institutions (NBFIs) started to come up, following the coffee boom. This was made possible due to low minimum capital requirement of NBFIs as compared to that of commercial banks. Thus, there was faster growth of the NBFIs deposits in relation to those of commercial banks. Interest rates underwent a series of reviews in a period spanning 1980-1990 to enable commercial banks compete favorably with NBFIs whose interest rates were very low (Ngugi, 2001). These adjustments were also aimed at controlling inflationary pressures. During this period, NBFls grew rapidly i.e. from 23 in 1981 to 48 in 1985. In addition, commercial banks increased from 16 to 24 during the period 1981-1988. There was a lot of competition between commercial banks and NBFIs as the deposit ratio of NBFIs to that of commercial banks increased from $34 \%$ in 1980 to $66 \%$ in 1990.

Due to trade reforms that were taking place across the world, interest rates were liberalized in Kenya in 1991. This led to a decline in the minimum rate of savings from $13.5 \%-6.6 \%$ in 1995 . However, the lending rates (maximum) increased to $38.6 \%$ (Tarus et al., 2012). As a result of this, interest spreads assumed an upward trend. Similarly, lending rates reached their peak at 38.6\% in 1993, a phenomenon which resulted into upward trend in the IRS. Liberalization of interest rate took place during periods of poor economic performance due to increasing inflationary pressures that resulted from fiscal policy expansionary measures. Interest rates increased further due to financing of the fiscal deficit through domestic borrowing. These changes led to a decline in the saving rates and an increase in the lending rates during the first half 1990's. The interest spread reached its peak in 1996. In the year 2012, CBK initiated various regulatory and institutional reforms with the intention of improving financial access, stability and efficiency in the banking industry. The main emphasis was to ensure that banks comply with regulatory framework (CBK, 2012). From 2012, there was no any significant development in policies to reduce interest rates apart from the normal regulatory mechanism by the CBK, until September 2016 when a banking amendment Act 2015 that sought to curb high interest rates charged by commercial banks was enacted into law. The new Act bars

1 This resulted from high transaction costs of interest rates and credit control 
INTERNATIONAL JOURNAL OF ACADEMIC RESEARCH IN BUSINESS AND SOCIAL SCIENCES

Vol. 8, No. 7, July 2018, E-ISSN: 2222-6990 @ 2018 HRMARS

commercial banks from charging more than $4 \%$ interest above the CBK base lending rate. In addition, commercial banks are obliged pay a deposit rate of $7 \%$.

\section{Literature Review}

Theoretically, the debate on the interest rate spreads started way back in 1945 by Samuelson while conducting investigation on the impact of interest rate on the financial sector (Samuelson, 1945). Ho \& Saunders (1981) was among the earliest researchers to use two-step model to investigate drivers of IRS using panel data. This model has now been modified and tested by several authors. Studies have used several theoretical perspectives in analysing the determinants of IRS. For example, Beck and Hesse (2009) found that information asymmetry between the participants in the financial intermediation system is very important. This study argued that information asymmetry between the lenders and borrowers may result into either a moral hazard or adverse selection challenges. These two problems can reduce the lender's ability to assess the potential borrower's credit worthiness. Hence, lenders may be tempted to impose a certain rate to take care of the risks that might occur such as inability of the borrowers to repay the loan. This situation is likely to increase IRS.

Demand and supply for loans in the financial markets was theorized to influence bank interest rates. In his theoretical view on credit, Anyanwu (1990) links interest rates with lack of savings, hoarding of money and inability to invest by government, businesses and consumers. This implies that banks determine interest rates based on the forces of demand and supply of loanable funds. It is probable that a higher demand for loans by bank's customers, is likely to attract higher interest rates on loans and vice versa. Keynesian in his liquidity theory postulated that demand and supply of money determines interest rates in an economy. In his school of thought, Keynes stated that interest rate is a purely monetary, not a reward for hoarding money but for giving out liquidity for a certain time (Pandey,1999). This theory makes two assumptions; one is that the economy is operating in the short run and two, money supply is given. The supply of money comes from banks and government while demand for money is the preference for liquidity. People and institutions like to hoard money because of liquidity preferences (Anyanwu,1990). Therefore, when banks lend money, they sacrifice liquidity preference, for the reward called interest rate. This then implies that the rate of interest is the reward that banks get for parting with cash (Crowley, 2007).

Empirical Studies have employed different methodologies across the world to investigate determinants of IRS. Demirguc-Kunt and Huizinga (1999) using a panel of 80 countries, argued that operating costs, bank size, liquidity and credit risks are among the key determinants of IRS. in addition, this study overserved that macroeconomic factors largely explained differences in the levels of interest and revenues among banks. Similar findings were observed by Carbo and Rodriquez (2007) and Siddiqui (2012) in Europe and Latin America respectively. In similar studies, Dabla-Norris and Floerkemeier (2007) and Horvath (2009) indicated that banks with more capital have lower spreads due to their lower risk of bankruptcy. On the other hand, Beck and Hesse (2009) did not observe any significant link between IRS and entry of foreign banks, privatization, market power and banking efficiency. In addition, this study argues that GDP and inflation have very little impact on interest rate spreads. Regarding bank specific factors, they argued that interest spreads are largely explained by time-invariant bank-level fixed effects.

A systematic comparative investigation of the drivers of IRS in Eastern and Western European countries found that market concentration, intermediation costs, capital and risk management, are vital determinants of IRS (Claeys \& Vennet, 2003). In addition, this study further established that initial stages of institutional reforms bring about risky bank behaviours which translates into high IRS, 
but as the reforms advance, interest rate spreads reduce because of intense competitive pressures in the industry. These findings are however, inconsistent with Barajas et al. (1999) who concluded that liberalization does not have any direct effect on narrowing the interest margins. The efficiency of the judiciary system in enforcing debt contract was found to influence IRS. Leaven and Majnoni (2005) used commercial banks data for 106 countries from the year 2000 up to 2006 to argue that judicial efficiency and inflation rates explained greatly interest margins across countries. The results from this study indicate that judicial efficiency in the enforcement of debt contracts reduce intermediation costs for firms and households which results to lower interest rate spreads.

The role of market structure and regulatory environment within the banking industry has been emphasized by many studies. Carbo and Rodriguez (2007) using Ho and Saunders (1981) framework discovered that regulations related to the entry of new banks, market structure and information exchange on borrowers influence the efficiency of intermediation process. The more a market is segmented, the higher the likely market power, which in turn increases IRS (Saunders \& Schumacher, 2000). Another study established that higher market power reduces competition and thereby increasing interest margins within baking sector. Demirguc-Kunt et al. (2004). However, greater market concentration can also result into more profits because of probably higher lending rates (Berger \& Hannan, 1989). Chirwa and Mlachila (2004) using panel data approaches, attributed high IRS to low competition, huge reserve requirements, high inflation and high discount rate of the central bank within the Malawian banking sector.

Imperfect institutions and high returns on Treasury bills are related to high IRS as observed by (Beck and Hesse, 2009) in Uganda. This study also observed that bank markets weakly explain IRS. Ahokpossi (2012) investigated the impact of bank specific variables on IRS by using data from 456 banks in sub-Saharan Africa. His findings indicated that provision for non-performing loans, capital, non-interest activities and inflation positively explained IRS. However, this study did not consider the influence of institutional factors which might have altered the results. A study by Wakemann-Linn et al. (2010) found lack of credit reference bureaus, poor legal systems and the presence of foreign banks significantly determine IRS in East Africa from 1998 to 2010. In an analysis of individual bank IRS in Nigeria, Hesse (2007) argued that big banks enjoy lower administrative costs than smaller banks and in turn, they have lower spreads. This study further revealed that liquidity risk and asset base were negatively correlated to the IRS.

The macroeconomic factors such as GDP and inflation affects the banking industry performance, by influencing borrower's ability to repay loans or to borrow (Ngugi, 2001). Poor economic performance proxied by GDP negatively affects returns on investment, which is likely to affect repayment of borrowed funds and thereby squeezing the bank margins (Ngugi, 2001). Inflation rates can influence IRS in the case where shocks within the monetary market are not managed well (Beck and Hesse, 2009). Similar findings were established by Bennaceur and Goaied (2008) for Tunisia, Chirwa and Mlachila (2004) for Malawi.

In summary, there is a lot of literature on determinants of IRS. However, there is no universally accepted findings on what determines IRS. For instance, the most recent studies on the determinants on IRS in Kenya by Were and Wambua (2013), and Kiptui (2014) are inconsistent on the effect of macroeconomic factors. In addition, we used the most recent data for commercial banks from January 2006- December 2015 during which there has been some changes in macroeconomic climate such as central bank rate, inflation and GDP. 
INTERNATIONAL JOURNAL OF ACADEMIC RESEARCH IN BUSINESS AND SOCIAL SCIENCES Vol. 8, No. 7, July 2018, E-ISSN: 2222-6990 @ 2018 HRMARS

\section{Theoretical Framework}

This study used the most influential work of Ho and Saunders (1981) and its subsequent modifications to analyze determinants of IRS. In their paper, the bank was presented as a risk averse agent between borrowers and depositors of money, where it asks for a gainful interest for giving out its liquid assets in terms of loans, while on the other hand, risking on the likely mismatch between demand for loans and arrival of surplus deposits. In their framework, Ho \& Saunders argued that the aim of the bank is to maximize the anticipated shareholder's profits. They further argued that imposing a charge, $q$ (fee for anticipated risk-free rate of interest), is the most appropriate way for a bank to balance deposits and loans demanded. This $q$, is projected to reduce rates on deposits $\left(R_{d}\right)$ by $c$ and increase interest on loans $\left(R_{l}\right)$ needed for loans by $e$. Summing up $c+e$ gives us the IRS necessary for the bank to provide loan and deposit services.

$R_{l}=q+e$

$R_{d}=q-c$

Where $R_{l}$ is interest imposed on loans while $R_{d}$ is interest charged on deposits, $c$ refers to bank charges for providing immediate liquidity services while, $e$ refers to the risk premium imposed to cater for risk refinancing. This framework also assumes a one planning period in which the rates of interest on loans and deposits remain the same after being reviewed at the commencement of a decision period. This assumption holds for only one transaction with equal sized deposit and loan for a pre-determined period.

Subsequent studies have extended Ho and Saunders model by modifying some of its assumptions. For example, Allen (1988) relaxed the assumption of loan homogeneity and showed that considering loan heterogeneity may lead to a decline in interest margins (IRS) due to bank diversification. By relaxing those assumptions, IRS were therefore assumed to be determined by risk premium and the monopoly strength. This means that in the case where risks are neutral, interest spreads are supposed to decline because risk premiums are not necessary; there are no uncertainties on loan demands and the arrival of deposits to be compensated for. Angbazo (1997) introduced credit and liquidity risks and how they interact with the risks inherent within the model. He noted that credit risk was a ratio of non-performing loans to total loans. The higher ratio implies higher cost of bad debts, which is expected to lead to higher IRS (Maundos \& De Guevara, 2004). The concept of liquidity was also introduced in the model where banks that have more liquid assets, are likely to get lower income from interest rate (Hesse, 2007). This in turn leads to lower spreads in the case of competitive market for deposits. However, banks in possession of more liquid cash, forgoes higher interest income and hence are likely to have higher spreads. Based on these observations, the liquidity ratio can impact IRS either positively or negatively.

Ho \& Saunders (1981) framework was modified further to account for bank's operating costs (Maudos \& De Guevara, 2004). Later on, the new model was used to calculate degree of market competition and market concentration index (Herfindahl index). Carbo and Rodriquez (2007) theorized that the changes in the degree of market concentration throughout the study period reduced the interest spreads. This was attributed to improvements made in efficiency due to economies of scale or improved level of competition in the sector. Concentration ratio was measured based on total loans advanced by the bank as well as assets base. The impact of capital was also introduced in the model where it was found out that more capitalized banks are said to be more cautious in their investment because they have more capital at risk (Maundos \& Solis, 2009). Therefore, capital is positively correlated to interest spreads. Considering all the modifications to Ho \& Saunders (1981) framework, the anticipated bank's utility was maximized by Maudos and De 
INTERNATIONAL JOURNAL OF ACADEMIC RESEARCH IN BUSINESS AND SOCIAL SCIENCES Vol. 8, No. 7, July 2018, E-ISSN: 2222-6990 @ 2018 HRMARS

Guevara (2004). This was achieved through the application Taylor expansion and symmetric and the linear functions of loan demand and supply. Then, they solved for the first order differentials in the charges imposed on deposits and loans separately. Resulting from these calculations, is the pure IRS, $s=c+e$ which is estimated by four factors:

1) Industry market power denoted as $\beta$;

2) Risk aversion, $R$ of the bank

3) Variance of interest rate $\left(\delta_{I}^{2}\right)$ and finally,

4) Bank size, $Q$ which was measured as a log of assets

Based on the above factors, IRS is defined as follows:

$s=R_{l}-R_{d}=(c+e)=\beta+\frac{1}{2} \mathrm{R} \partial_{I}^{2} Q$

Where, $R$ is the coefficient of the bank's risk aversion.

\section{Empirical Model}

This study had sought to describe factors determining IRS in Kenya. To do that, regression analysis based on Ho \& Saunders (1981) framework and its extensions were used. In this paper, regulatory and macroeconomic variables are also included. In particular, the empirical model was expressed as: $r_{i t,}=z+\beta_{1} B_{i t,}+\beta_{2} M S_{i t}+\beta_{3} M E_{t}+\varepsilon_{i t}$

Where $r_{i t}$, is IRS for bank $i$ in year $t, z$ is the intercept representing pure spread which varies with time and is equal for all banks. This intercept captures the effects of unobserved or omitted variables, $B_{i t}$ is a vector of determinants of banks interest spread based on the theoretical framework, MS is a vector of market structure (market power), ME (Real GDP, Inflation, Exchange rate) represents vectors for macroeconomic variables while $\boldsymbol{\varepsilon}_{\boldsymbol{i}}$, is a statistical error term. In addition, the study adds reserve requirements as a regulatory variable following (Crowley, 2007). Reserve requirement is the amount of money commercial banks are required to deposit with the central bank for monetary policy purposes. These reserves are non-interest-bearing assets on the side of the commercial bank and therefore impose a tax on banks hence reducing their revenues. Furthermore, dummies for bank ownership to establish if ownership of the bank have any impact on IRS were introduced. Banks were categorized as owned by government, private or foreign owned.

Based on the factors influencing of IRS as suggested by theoretical framework, estimated:

$I R S_{i t}=z_{0}+\alpha_{1} B S_{i t}+\alpha_{2} C R_{i t}+\alpha_{3} L R_{i t}+\alpha_{4} R O A_{i t}+\alpha_{5} M C_{i t}+\alpha_{6} R R_{i t}+\alpha_{7} R G D P_{t}+\alpha_{8} F o B+$ $\alpha_{9} G o B+\alpha_{10} P o B+e_{i t}$

Where $z_{0}$ is the intercept

FoB, GoB and PoB are dummies for Foreign, Government owned and Private owned banks respectively.

$\mathrm{e}_{\mathrm{it}}=$ error term and $\mathrm{i}$, represents bank $\mathrm{i}$, while $\mathrm{t}$ represents time $\mathrm{t}$ (years). 
INTERNATIONAL JOURNAL OF ACADEMIC RESEARCH IN BUSINESS AND SOCIAL SCIENCES Vol. 8, No. 7, July 2018, E-ISSN: 2222-6990 @ 2018 HRMARS

Table 1: Description of Variables

\begin{tabular}{|c|c|c|}
\hline Variables & Proxy/measurement) & Hypothesized relation \\
\hline $\begin{array}{l}\text { Interest rate } \\
\text { spread }\end{array}$ & IRS=lending rate- deposit rate & Dependent variable \\
\hline Bank Size & BS=log bank's Capital & $\begin{array}{l}\text { Positive correlation with IRS for big } \\
\text { banks }\end{array}$ \\
\hline Credit Risk & $C R=\frac{\text { Non }- \text { performing loans }}{\text { Total loans }}$ & Positive sign \\
\hline Liquidity Risk & $L R=\frac{\text { Liquid assets }}{\text { Total assets }}$ & $\begin{array}{l}\text { Higher ratio means lower LR and } \\
\text { hence lower IRS }\end{array}$ \\
\hline $\begin{array}{l}\text { Return on Average } \\
\text { capital employed }\end{array}$ & $R O A=\frac{\text { Profit }(\text { loss })}{\text { Average Capital employed }}$ & $\begin{array}{l}\text { Positive correlation with IRS is } \\
\text { expected }\end{array}$ \\
\hline $\begin{array}{l}\text { Market } \\
\text { Concentration }\end{array}$ & $M C: H H I=\sum_{i=1}^{N} s_{i}^{2}$ & $\begin{array}{l}\text { A more concentrated banking } \\
\text { sector implies less competition and } \\
\text { hence high IRS for a bank. }\end{array}$ \\
\hline $\begin{array}{l}\text { Reserve } \\
\text { Requirement }\end{array}$ & RR: Reserve Requirement (Given) & $\begin{array}{l}\text { RR is hypothesized to have a } \\
\text { positive relationship }\end{array}$ \\
\hline Economic Activity & RGDP: Real Domestic Product (given) & $\begin{array}{l}\text { Higher RGDP is projected to } \\
\text { increase demand for loans. This is } \\
\text { likely to increase lending rates. } \\
\text { But, also increase in GDP } \\
\text { (economic activities) can make } \\
\text { businesses more profitable, } \\
\text { reduce amounts of bad debts, and } \\
\text { increase deposits all of which may } \\
\text { reduce lending rates. }\end{array}$ \\
\hline
\end{tabular}

\section{Data and Estimation Process}

Data was obtained from CBK database and Economic survey reports. CBK has consistent micro-data for all commercial banks from 2006 to 2015. This data is compiled from published financial statements of commercial banks. The data consisted of annual observations of deposit and lending rates, loans and non-performing loans, operating expenses, bank assets, market share index and capital, real GDP, bank profitability, reserve requirements and inflation among other variables. Real GDP annual data was obtained for various economic survey reports.

The study utilized pooled OLS, Random and Fixed effect regression equations to estimate the determinants of IRS (equation 5). This is because OLS sometimes fails to account for individual specific effects as well as controlling for outliers which might result into biased results. This approach was advantageous because it allowed modelling for individual heterogeneity (Wooldridge, 2006). Panel data gives more insights than either cross-sectional or time series. This is because panel data allow for isolation of specific effects and actions (Hsiao,2007), and therefore it takes into consideration bank specific factors for the case of this study. 
INTERNATIONAL JOURNAL OF ACADEMIC RESEARCH IN BUSINESS AND SOCIAL SCIENCES Vol. 8, No. 7, July 2018, E-ISSN: 2222-6990 @ 2018 HRMARS

To check the model specification to control accurately the probability of wrongly rejecting the null hypothesis, the study employed Hausman test. With Prob $>c h i^{2}=0.4547$ which is more than 0.05 , the study accepted null hypothesis that random effect was the most suitable model. After ascertaining the suitable model, the study had to check whether there was serial correlation in the model. To do this, Pasaran CD test was used. This tests for the correlation of variables with residuals. One of the causes of this problem is endogeneity in the data sets. The study tested null hypothesis of no serial correlation. With Prob $>=0.0712$, the study accepted the null hypothesis.

\section{Results}

IRS is a fundamental element in the Kenya's economy due its impact on savings, deposits and hence, investments. A total of 38 commercial Banks were included in the panel. Data contained all the factors which are believed to theoretically explain IRS. These included bank assets, capital, loans and advances to customers, non-performing loans, quick cash, bank profitability, interest margins, reserve requirements, interest expenses, real GDP among others. The paper presents descriptive as well as econometric analysis of the results.

\section{Descriptive Analysis}

Among the issues examined are the trends in interest rate spread in East Africa, trends of IRS by bank categories, the share of loans and deposits by bank categories. East African Community Facts and Figures (2015) indicate that Kenya has the highest IRS followed by Uganda, Rwanda and Burundi, while Tanzania has the lowest IRS on average (see Figure 1). However, there is a general decline of IRS in Kenya as from 2011, the opposed to other countries in East Africa.

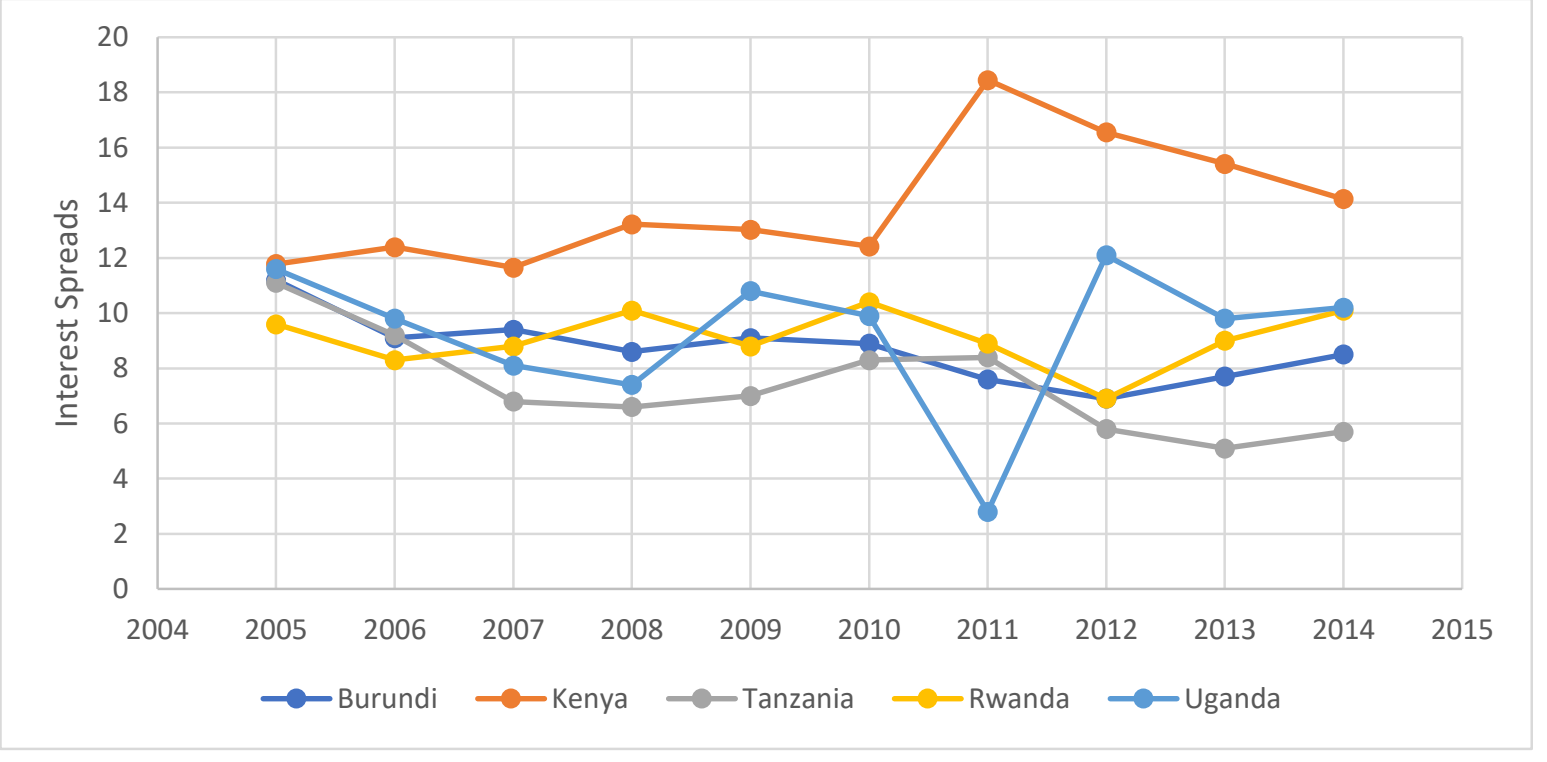

Figure 1: Interest spread across East Africa (2005-2014)

Source: EAC Facts \& Figures (2015)

Regarding IRS by bank categories, Figure 2 indicate that large banks had relatively higher IRS as compared to both medium and small banks between 2006 and 2015. This trend further reveals that there have been fluctuations with no definite trend on IRS for all bank categories between 20062015. This could be attributed probably to the fluctuations in economic activities, the crisis like the political turmoil in 2007/2008, economic crisis of 2008 among other shocks. 
INTERNATIONAL JOURNAL OF ACADEMIC RESEARCH IN BUSINESS AND SOCIAL SCIENCES Vol. 8, No. 7, July 2018, E-ISSN: 2222-6990 @ 2018 HRMARS

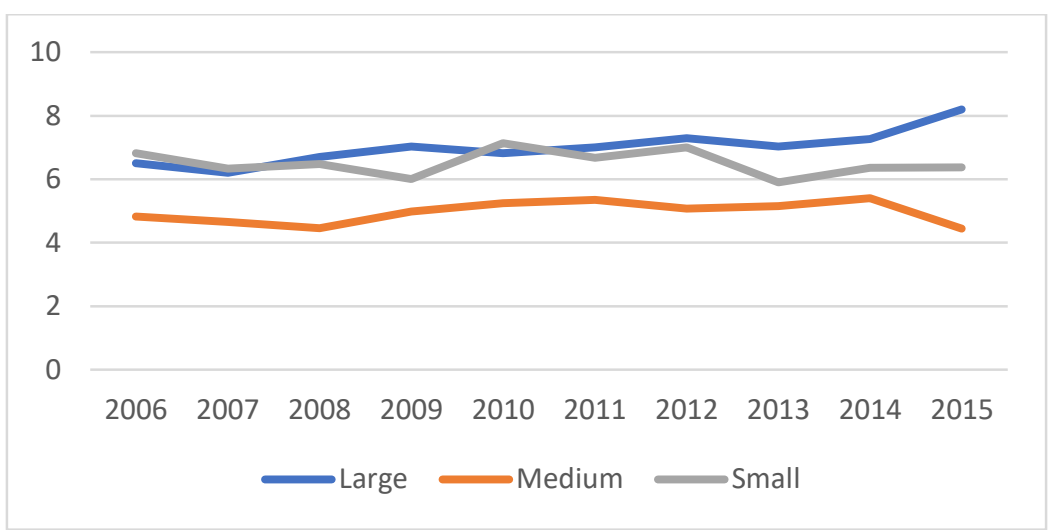

Figure 2: Interest Rate Spread across bank categories

Source: Computed from CBK data

Turning to loans and advances, Figure 3 presents a summary of the results by bank categories for the years 2006, 2010 and 2016

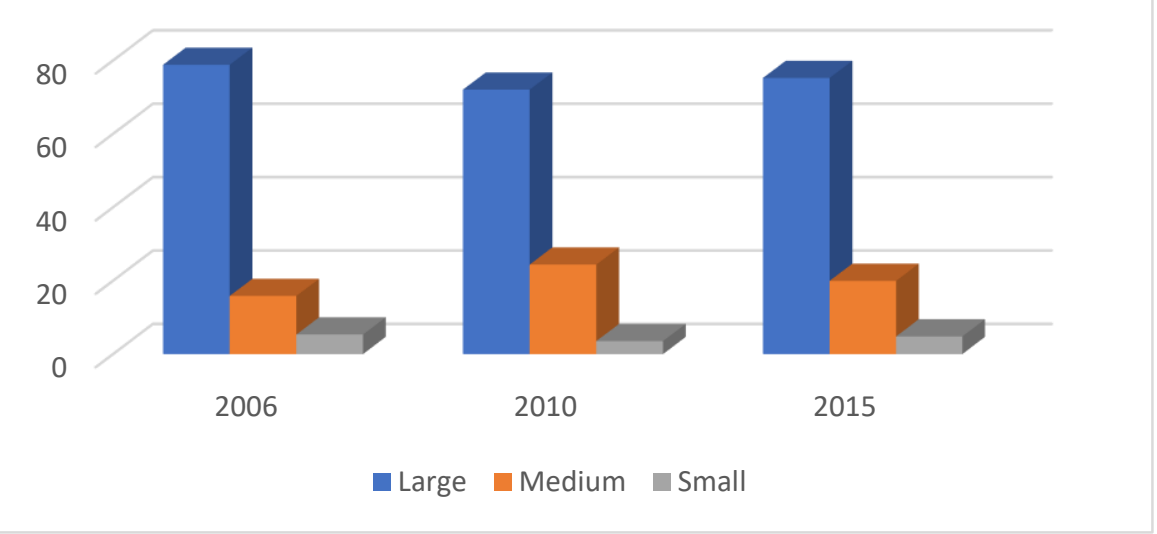

Figure 3: Percentage share of loans and advances by Bank Categories

Source: Computed from CBK data

Figure 3 shows that large banks accounts for more than $70 \%$ of lending. They are closely followed by Medium banks with slightly over $15 \%$. These indicate that the market for loans is dominated by large banks.

\section{Econometric Results}

We applied panel data models to for the study. Three regressions were conducted, that is, pooled OLS, Fixed Effect (FE) and Random Effect (RE) regressions to analyze the determinants of IRS. For the model suitability, the study employed Hausman test to determine which model between FE and RE was suitable for the study. Null hypothesis of the test stated that RE model was preferred against the alternative hypothesis in favor of FE model. The test predicts whether unique errors $\left(\varepsilon_{i}\right)$, were correlated with predictors with the null hypothesis stating the opposite. We accepted null hypothesis for RE model at $10 \%$ significance level, which confirmed the suitability of the model for this study. This means that bank heterogeneity (differences across banks) such management style or quality, work force competencies, among others leads to variations in the interest rate spreads. That notwithstanding, the three models used; Pooled OLS, FE and RE, yielded almost similar results as shown in Table 2. F-Statistics tests for all the three models ( 0.000 for Pooled OLS, 0.0019 for RE and 0.0001 for $\mathrm{FE}$ ) rejected the null hypothesis that explanatory variables have zero (0) coefficients and 
INTERNATIONAL JOURNAL OF ACADEMIC RESEARCH IN BUSINESS AND SOCIAL SCIENCES

Vol. 8, No. 7, July 2018, E-ISSN: 2222-6990 @ 2018 HRMARS

hence, ascertaining the validity of the models. On the other hand, the R-squared statistics of the three models showed that explanatory variables weakly explained the dependent variable. For OLS, explanatory variables explained the dependent variable by $18.68 \%$ and this percentage dropped to $12.37 \%, 9.2 \%$ for RE and FE models respectively.

Table 2: Pooled OLS, RE, and FE results

\begin{tabular}{llll}
\hline \multirow{2}{*}{ Variable } & Pooled OLS & RE & FE \\
\cline { 2 - 4 } & Coef & \multicolumn{1}{l}{ Coef } & Coef \\
BS & $-1.17(0.195)^{* * *}$ & $-0.867(0$. & \\
CR & $218)^{* * *}$ & $-0.81(0.24)^{* * *}$ \\
LR & $0.320(1.343)$ & $-0.144(0.94)$ & $-0.0084(0.919)$ \\
ROA & $-1.729(0.653)^{* * *}$ & $0.188(0.381)$ & $0.355(0.365)$ \\
& $0.035(0.007)^{* * *}$ & $0.01(0.004)^{* * *}$ & $0.01(0.004)^{* * *}$ \\
MC & & & $0.003(0.001)$ \\
RR & $0.0002(0.0001)$ & $-0.000(0.000)$ & $* * *$ \\
& $.0003(0.0001)^{* * *}$ & $0.0001(0.000)^{* *}$ & $-9.70(0.000)$ \\
RGDP & & $0.0004(0.0001)$ & \\
FoB & $0.0003(0.0002)^{*}$ & $* * *$ & $0.0003(0.00)^{* *}$ \\
GoB & $0.76(0.684)$ & $0.74(1.62)$ & 0.00 \\
PoB & $1.7(0.815)^{* *}$ & $1.987(1.94)$ & 0.00 \\
Constant & $-0.394(0.663)$ & $-0.283(1.56)$ & 0.00 \\
Number of obs & $14.16(2.37)$ & $12.87(3.29)$ & $-2.86(5.87)$ \\
Number of groups & 363 & 363 & 363 \\
Prob $>$ F & 0.000 & 38 & 38 \\
R-squared & 0.000 & 0.0019 & 0.0001 \\
sigma_u & 0.1868 & 0.1237 & 0.092 \\
sigma_e & & 1.93 & 5.26 \\
Rho & & 1.33 & 1.33 \\
\hline
\end{tabular}

NB. In brackets are standard errors $* * *, * *$ and $*$ are $1 \%, 5 \%$ and $10 \%$ significant levels.

Econometric results for bank specific factors included in the study show that bank size (BS) and the return on average assets (ROA) are highly significant at $1 \%$ level for all the three models. The negative sign on the coefficient for BS show that IRS declines with an increase in the size of the bank. Various studies have reported similar findings (Dabla-Norris \& Floerkemeier, 2007, Horvath, 2009) where it was argued that large banks have lower spreads due to their lower risk of bankruptcy. These results are also consistent with the theory of economies of scale, such that large banks can afford to invests in sophisticated technologies and hence lower their operational costs which could result to low IRS. Th BS is also reported to have a big impact on IRS. If higher IRS can be associated with inefficiencies, then the conclusion from this study is that smaller banks are less efficient relative to large banks. This is a more logical conclusion since big banks can afford better, and cost reducing technologies which may result into lower pricing of their products. In addition, the coefficient of ROA is also positive, although its impact is very small. This relationship could imply the behavior of the commercial banks to maximize profits, where banks with high profit margins as compared to their assets value, could 
INTERNATIONAL JOURNAL OF ACADEMIC RESEARCH IN BUSINESS AND SOCIAL SCIENCES Vol. 8, No. 7, July 2018, E-ISSN: 2222-6990 @ 2018 HRMARS

be charging higher borrowing rates than deposit rates. This observation is an indication of low competition in the Kenya's banking industry. That notwithstanding, this positive relationship can be disputed based on the similar arguments on bank size, meaning that higher ROA should be linked to lower IRS. Similar results were reported by Siddiqui (2012).

Credit risk (CR) is found to lower the interest spreads while an increase in Liquidity risk (LR) increases IRS, though these two variables are not statistically significant. The reason why the coefficient of CR is negative could be that even though non-performing loans to total loans ratio is high, commercial banks may not after all pass on the risks to their customers through higher lending rates. This move may be aimed at encouraging customers to repay their loans in an effort to reduce non-performing loans. Similarly, Hesse (2007) who found negative correlation between interest spread and the credit ratio (CR). However, Ngugi (2001), Becke et al. (2009) reported positive and significant relationship between CR, LR and IRS. Market concentration (MC), a proxy for macro-industry specific factors was only found to be highly significant but less impactive under FE model.

An increase in economic activities captured by Real Gross Domestic Product (GDP) has the effect of increasing interest rate spreads as noted by the results. Although RGDP is highly significant (1\%) under RE results, its coefficient (0.00004), indicates that the variable has less impact on IRS. Both FE and OLS models also found RealGDP as a significant factor at $10 \%$ and $5 \%$ levels respectively. Other studies in Africa which have found similar results are: Bennaceur and Goaied (2008) for Tunisia, Becke and Hesse (2009) for Uganda and Kiptui (2014). However, Were and Wambua (2013) for Kenya, argued that economic growth rate does not impact on the IRS. An analysis of Were and Wambua (2013) study revealed that they did not include other variables such as reserve requirements, which might have occasioned the differences. With respect to regulatory environment (monetary policy), the study found a positive sign of RR for both OLS and RE models, implying that higher RR increases IRS. Although the coefficient was statistically significant, its impact on IRS was very small. Bank ownership exerts no influence on IRS according to both fixed and random effect results except for government owned banks (GoB) under OLS estimates.

\section{Conclusion and Policy Recommendation}

Liberalizing of the banking sector was to ensure efficiency in the financial intermediation process so as spur economic growth and development. However, there has been no tangible results particularly in the sub-Saharan Africa countries including Kenya for more than two and half decades of embracing these policies. In fact, IRS in Kenya are closely comparable to the mean IRS for the Sub-Saharan region and higher in the EAC (Were \& Wambua, 2013). While the drivers of IRS are expected to be manysided, this study empirically gives some insights based on bank, industry and macroeconomic factors using the same approaches applied in other studies.

By applying panel data estimations, the results indicate that bank-specific factors are significant towards determining IRS in the banking industry. These factors are; the size of the bank, return on average assets, credit and liquidity risks. Real GDP, a proxy for macroeconomic environment was also statistically significant. The impact of monetary policy on IRS as proxied by reserve requirements was also asserted vividly by the study. Although it was found to be positively related to IRS, its impact is weak. This could arguably mean that there is a weak response by commercial banks to monetary policy indicators. The study therefore concluded that bank, industry and macroeconomic factors influence IRS. However, the influence of credit risk, bank size, liquidity risk, ROA, market concentration, reserve requirements, and real gross domestic product) was very minimal. Finally, dummy variables for bank ownership were not significant. 
Summing up, the relatively high IRS in Kenya is still a topic which will continue to generate debates in the public fora in the future. The recent introduction of interest rate capping policy may not provide the highly-sought solution of effective financial intermediation in Kenya because such a policy has failed in other economies such as Romania, Panama and Cyprus, just to mention but a few (Munzele \& Alejandra, 2014).

Even though there is an increased competition in the Kenyan banking sector, there is need to improve it through relevant policies. This should be accompanied by strategies to improve the growth of small and medium sized banks to break dominance of the few big banks in the industry and reduce IRS. It may take the form of public education on the importance and stability of the medium banks in the sector. In addition, there is need to explore both internal and industry-led strategies to reduce the effects of some of the bank specific factors like ROA which are driving high IRS. These could range from adopting cost-effective technologies and diversification of bank products which can reduce over reliance on interest income and its related perils.

\section{References}

Ahokpossi, C. (2012). Determinants of Bank Interest Margins in sub-Saharan Africa. IMF Working Paper 13/34, Washington, DC

Allen, L. (1988). The determinants of bank interest margins: A note. Journal of Financial and Quantitative Analysis, 23 (2), 231-235

Afzal, A. (2011). Interest rate spreads, loan diversification and market discipline in Pakistan's commercial banking sector. (Unpublished PhD thesis), University of Pakistan

Angbazo, L. (1997). Commercial bank Net Interest Margins, default risk, interest rate risk and offbalance sheet banking. Journal of Banking and Finance, 21, (1), 55-87

Anyanwu, J.C. (1990). Monetary Economics Theory Policy and Institutions. Victoria (Australia): Hybrid Publishers Ltd.

Barajas, A., Steiner, R., and Salazar, N. (1999). Interest Spread in Banking: Costs, Financial Taxation, Market Power and Loan Quality in the Colombian Case, 1974-1988, IMF Working Paper No. 110. Washington, D.C. World Bank

Beck, T., Cull, R., Fuchs, M., Getenga, J. Gatere, P., Randa, J., and Trandafir, M. (2010). Banking Sector Stability, Efficiency and Outreach in Kenya, World Bank Policy, Research Working Paper 5442, Washington DC: The World Bank

Beck, T., and Hesse, H. (2009). Why are interest rates spreads so high in Uganda? The Journal of Development Economics, 88, 192-204

Bennaceur, S., and Goaied, M. (2008). The Determinants of Commercial Bank Interest Margin and Profitability: Evidence from Tunisia, Frontiers in Finance and Economics, 5 (1), 106-130

Berger, A. N., and Hannan, T.H. (1989). The Price-Concentration Relationship in Banking, Review of Economics and Statistics, 71 (2):291-99

Brook, P., and Rojas-Suareza, L. (2000). Interest Rate Spreads in Latin America. In Why So High? Understanding Interest Rate Spreads in Latin America, edited by Philip Brock and Liliana Rojas-Suarez, pp. 1-38. Washington, D.C., Inter-American Development Bank.

Carbo, S., and Rodriguez, F. (2007). The determinants of banks' margins in European banking. Journal of banking and Finance, 31: 2043-2063

Central bank of Kenya (2015). Annual Report

Central bank of Kenya (2012). Annual Report

Central bank of Kenya (2013). Bank Supervision Annual Report 
INTERNATIONAL JOURNAL OF ACADEMIC RESEARCH IN BUSINESS AND SOCIAL SCIENCES

Vol. 8, No. 7, July 2018, E-ISSN: 2222-6990 @ 2018 HRMARS

Chirwa, E.W., and Mlachila, M. (2004). Financial Reforms and Interest Rate Spreads in the Commercial Banking System in Malawi, International Monetary Fund (IMF) Staff Papers, 55(1): 96-122

Claeys, S., and Vennet, R.V. (2003). Determinants of Bank Interest Margins in Central and Eastern

Europe: A comparison with the West, Working Papers of Faculty of Economics and Business

Administration, Ghent University, Belgium 03/203

Crowley, J. (2007). Interest Rate Spreads in English-Speaking African Countries, IMFWorking Paper No. wp/07/101). Washington D.C. World Bank.

Dabla-Norris, E., and Floerkemeier, H. (2007). Bank Efficiency and Market Structure: What Determines Banking Spreads in Armenia? Washington, International Monetary Fund, Working Paper No. $07 / 134$

Demirguc-Kunt, A. Laeven, L., and Levin, R. (2004). Regulations, market structure, institutions, and the cost of financial intermediation, Journal of Money, Credit and Banking, 36 (3), 593-622.

Demirguc-Kunt, A., and Huizinga, H. (1999). Determinants of Commercial Bank Interest Margins and Profitability: Some International Evidence, World Bank Economic Review, 13 (2), 379-408

Dumicic, M., and Ridzak, T. (2013). Determinants of bank's net interest margins in central and eastern Europe. Financial theory and practices, 37 (1), 1-30

East African Community (2015). Facts and Figure

Gunter, U., Krenn, G., and Sigmud, M. (2013). Macroeconomics, Market and Bank-Specific Determinants of the Net Interest Margin in Austria. Financial stability report, 25

Hesse, H. (2007). Financial intermediation in the pre-consolidated banking sector in Nigeria, Policy Research Working Paper Series 4267, Washington: World Bank

Ho, T.S., and Saunders, A. (1981). The determinants of bank interest margins: theory and empirical evidence, Journal of Financial Quantitative Analysis, 16, 581-600

Horvath, R. (2009). Interest Margins Determinants of Czech Banks. Institute of Economic Studies, Faculty of Social Sciences, Charles University, WP 11/09

Hsiao, C. (2007). Analysis of Panel Data. New York: Cambridge University Press

Kiptui, M.C. (2014). Determinants of Interest Rate Spread: Some Empirical Evidence from Kenya's Banking Sector. International Business Research, 7(11), 94-107

Leaven, L., and Majnoni, G. (2005). Does judicial efficiency lower the cost of credit? Journal of Finance, 29 (7), 1791-1812

Maudos, J., and Fernandez De Guevara. (2004). Factors explaining the interest margin in the banking sectors of the European Union. Journal of Banking and Finance, 28, 2259-2281

Maudos, J., and Solis, L. (2009). The determinants of net interest income in the Mexican banking system: an integrated model. Journal of Banking and Finance, 33, 1920-1931

Mensah, S., \& Abor, J. (2012). Agency Conflict and Bank Interest Spread in Ghana. Working Paper, University of Ghana, Legon

Munzele, S.M., and Alejandra, C.H.G. (2014). Interest Rate Caps around the World: Still Popular, but a Blunt Instrument, Policy Research Working Paper, 7070

Ngugi, R. (2001). An Empirical Analysis of Interest Rate Spread in Kenya. African Economic Research Consortium Research Paper 106, Nairobi, AERC.

Ngugi, R.W., and Ndung'u, N. (2000). Banking Sector Interest Rate Spreads in Kenya, KIPPRA Discussion Paper No.5.

Pandey, I. M. (1999). Financial Management. Journal of Banking and Finance, 10, 202-240 
INTERNATIONAL JOURNAL OF ACADEMIC RESEARCH IN BUSINESS AND SOCIAL SCIENCES

Vol. 8, No. 7, July 2018, E-ISSN: 2222-6990 @ 2018 HRMARS

Ramful, P. (2001). Determinants of interest rate spread: Empirical evidence in Mauritian banking sector. Research Department, Bank of Mauritius. Retrieved from https://www.bom.mu/pdf/Research_and_Publications/Research_Papers/spread.htm

Samuelson, P. (1945). The effects of interest rate increase on the banking system. American Economic Review, 35 (March), 16-37

Saunders, A., and Schumacher, L. (2000). The determinants of bank interest rate margins: an international policy. Journal of International Money and Finance, 19 (1), 813-832

Siddiqui, M.A. (2012). Towards Determination of Interest spread of Commercial Banks: Empirical Evidences from Pakistan, African Journal of Business Management, 6(5), 1851-1862

Tarus, K.D., Chekol, Y.B, and Mutwol, M. (2012). Determinants of the Net Interest rate margins of Commercial Banks in Kenya: A Panel Study, Procedia Economics and Finance, 2(2012), 199-208

Wakemann-Linn, J., Jarotschikin, A., Bashagi, A., Kessy, P., and Reweta, W. (2010). Bank Spreads in the EAC: 1998-2010. Mimeo

Were, M., and Wambua, J. (2013). What factors drive interest rate spread of commercial banks? Empirical evidence from Kenya, Review of Development Finance, 4 (2014), 73-82

Wooldridge, J.M. (2006). Introductory Econometrics (4th ed): A Modern Approach. Michigan: SouthWestern Cengage Learning 